\title{
CREATING AND POSITIONING THE IMAGE OF A TERRITORIAL UNIT
}

\author{
Wiesław CIECHOMSKI \\ Uniwersytet Ekonomiczny w Poznaniu; w.ciechomski@ue.poznan.pl, ORCID: 0000-0002-2310-8378
}

Purpose: The aim of this article is to characterize and analyse the activities undertaken by the authorities of territorial units such as cities, municipalities and districts for the purpose of creating their identity and image.

Design/methodology/approach: The paper applies the method of descriptive characterization of market phenomena and processes as well as referring to the literature on spatial marketing. Findings: There is a feedback loop between the objective identity of a given town or city and its subjective image because the unique identity promotes the creation of an optimal image, while the unique image determines the undertaking of specific actions aimed at building identity; including such elements of visual identity as the place's logo, coat of arms and flag, markings on the vehicles of town institutions, etc.

Originality/value: The author comprehensively describes the category of a spatial unit's image, its definitions and functions, and then proceeds to issues of classifying image types, the identity of a place brand, as well as place brand management, which is also referred to as destination branding.

Keywords: place marketing, promotion of a town/city, image.

Category of the paper: General review.

\section{Introduction}

Image creation is a subject of interest of many marketing theorists and practitioners. It concerns enterprises, product brands, non-profit organizations as well as local government units. The appropriate image of a city or region is not created automatically, but is a consequence of time-consuming and costly public relations activities and other promotion instruments. Creating an optimal image of a spatial unit such as a town, city, municipality, district or region is one of the main tasks of place marketing (Ciechomski, 2017, p. 130). 
Image can be defined as the subjective reflection of a brand, including any associations connected with it and which help to distinguish it from competitors. These associations can be both material and emotional, but it is the latter that are of key importance. In this context, the image of a territorial unit is assumed to include all the beliefs, opinions and impressions that the public hold about it. What is important, then, are primarily subjective impressions and perceptions rather than objective information. A territorial unit has no direct impact on how it is perceived by residents, tourists or investors, but it can try to create positive associations, as a result of which its image will be regarded as being more favourable.

Image is a set of subjective images of reality, created in people's minds as a result of perception, the influence of the media and informal messages. The image of a town or city is characterized by several properties, which include the following:

- it is individualised,

- it is not permanent,

- $\quad$ is shaped over a long period of time,

- is an internally complex feature,

- it can increase or decrease the place's competitiveness,

- its identification requires special marketing research (Szromnik, 2016, p. 147).

The attractive image of a spatial unit must be built on a credible foundation. This process is based on building a city's identity around such elements that are likely to cause a positive response from the recipients of the promotional activities. The process of building a city's identity is complex and should be based on the specific advantages of a given place (Markowski 2006, p. 129). The identity of a settlement unit is a multidimensional and comprehensive notion created as a result of planned, rational and long-term actions, consisting in popularizing its typical features and functions in the environment.

\section{Definitions of the image of a territorial unit and its functions}

Image, as a category of modern marketing, has been the subject of widespread discussion, research and analysis for several decades. The concept of image pertains to many different entities, including people, organizations, events, processes, material goods, ideas, brands and settlement units (Budzyński 2012, p. 19 et seq.). One of the more graphic definitions describes image as a multi-layered creation composed of diverse perceptions and observations, which is the result of processing in the human mind a mosaic of previously recorded images and information about a given entity (Szromnik 2012, p. 144). Thus, it comprises certain notions related to an individual perception of reality. 
Image should be considered in two contexts. The first one shows what the recipient is in contact with, while the second one shows the recipient's attitude to what they are experiencing. The same spatial features can be assessed differently by different recipients, and can have different values for different people. The image of an individual entity is a cognitive category describing the sum of subjective opinions, emotions and associations that people have with regard to a specific entity. Brand image can also be treated as a promise and the ability to fulfil it in the long term (Neal, Strauss 2008). Thus, a brand performs the function of not only a communicator but also a value generator (Hankinson, 2004, p. 109). Image consists of emotional, behavioural and cognitive elements (Hosany, Ekinci, Ujsal 2006, p. 638).

Image, as a carrier of the features of a given territory, performs several important functions: simplifying, ordering, minimizing risk and orienting. The simplifying function means a selective perception of certain features or behaviours. This means that only certain features of a given place become rooted in a recipient's consciousness, which affects their perception. This function is responsible for getting through to customers with the information that is most important to them. The next function, ordering, is responsible for systematizing the information received by the customer into a coherent whole (Florek, 2013, p. 84). This function means that new information about a given place is added to previous information. The recipient must organize and verify the incoming information. The risk minimization function means that the recipient of the promotional message is guided in their decisions, for example those related to tourism or financial investments, by the created image of a town or city. The orientation function concerns the process of information flow to appropriate addressees. In the midst of information chaos, the image of a city is the first pointer that helps in making decisions and taking the right course of action (Szromnik, 2012, p. 153).

There are many different classifications of images, which result from branding processes. Images are classified according to selected features. For example, one can distinguish the primary and secondary image, or the ideal image and the image of competitive brands. In the latter classification, the image corresponding to the ideal perception of the brand by the target group and the image of competing brands as perceived by the users are identified. In the former case, the primary image is determined mainly by promotional activities, while the secondary image is created when the customer has direct contact with the brand and gets a personal experience of the brand product (Szulce, Janiszewska, 2012, p. 43).

It is also possible to distinguish and define the following other types of images:

- own and external: own image is the current image formed in the minds of the city's inhabitants, while external image is considered from the point of view of identity elements systematized in the minds of groups of recipients from the broadly understood environment,

- individual and collective: the image created by a specific person or a group of people, which in the latter case is a certain average of the images created in the minds of all the members of a given community, 
- real and mirror: the real image is fixed in the minds of local government employees and is a mental reflection of the identity of the place, while the mirror image is a way of perceiving a spatial unit by individual members of local government bodies, e.g. heads of municipalities, or town or city mayors,

- desired and target: the desired image is the result of planning and implementing appropriately selected elements of the city's identity by the people responsible for creating its image. This is the image expected by the institutions and bodies in charge of a territorial unit. The target image is defined as a hypothetical image of identity, a rather distant vision of a place, which is consciously and deliberately shaped by the authorities in order to achieve it and maintain it in the long term (Szromnik, 2012, p. 155). The desired image should reach the consciousness of the target groups and stay there as long as possible because this image is the most important from the point of view of long-term destination branding. Improving the image of local government units (LGUs) and preparing for the implementation of specific procedures with regard to crisis management is a constant challenge for the authorities of spatial units and the staff of town or city promotion departments. Examples of possible crisis situations include residents' protests against building sewage treatment plants, waste incineration plants, etc.

\section{The image and identity of a place brand}

Image and identity are not synonymous. These concepts are often mistakenly thought to mean the same, whereas in fact they are complementary. It is necessary to define them precisely in order to properly understand the branding process of a settlement unit, which in a simplified way can be described as the process of transforming the original, initial image of a place into the intended target image, consistent with the developed place brand (Kall, Kłeczek, Sagan, 2006, p. 13). The desired image can be achieved, among other things, as a result of long-term and properly planned place brand management. Building the appropriate identity of a place is crucial for obtaining its desired image and is a key element in the process of building and managing the place brand.

Image can be defined as an external aspect which is described by means of the entity's selfpresentation. Identity, however, as an internal aspect can be defined as a certain set of characteristics that identify a given entity and distinguish it from others (Orfin-Tomaszewska, 2016, p. 47). The notion of identity can be analysed within the place marketing concept on the basis of various geographical or administrative divisions (Raszkowski, 2013, p. 228). 
The identity of a town or city is a primary concept in relation to image creation, because it determines the framework of actions. When shaping the image, it is important to use individual identity characteristics, i.e. its unique, specific attributes. Specialists dealing with the promotion of a town or city should strive to ensure that its image is consistent with its identity. Having a unique, positive and distinctive image is one of the methods of achieving competitive advantage among territorial units (Glińska, 2008, p. 36).

The concept of place identity arose in analogy to the concept of corporate identity. A city, like an organization, is a collection of various functions, has a management system and possesses resources that it uses to achieve its main aim; which in the case of a territorial unit is primarily improving the living conditions of the residents. Thus, just like in the case of a business organisation, the identity of a spatial unit can be defined as a comprehensive notion, shaped by long-term, planned and rational actions consisting in disseminating and promoting the place's characteristic features, properties and functions in the environment. Identity is therefore a multidimensional set of information about the town or city, purposefully compiled and communicated to all groups of recipients in order to achieve the desired image of the place (Florek, Augustyn, 2011, p. 147). The final effect, which is the place brand image, should be consistent with the previously formulated goals and assumptions that take into account the specific factors and conditions of the place.

The identity of a territorial unit is a unique combination of symbolic values and functional attributes. It usually has its sources in the actual resources and characteristics of a given territory. Therefore, the possibilities for developing the brand of a town or city are determined by its individual sub-products, their number and variety, which can become a distinguishing feature of the place (Ciechomski, 2015, p. 87; Florek, Augustyn, 2011, p. 14).

The identity of a town or city contains static elements such as location, traditions, history, cultural heritage, which do not change over time; as well as flexible elements, which undergo some evolutionary transformations. These transformations result from the need to adapt to the environment and changing socio-economic needs. A place's identity reflects its special and unique character. The identity is constantly evolving, adjusting to new social and economic realities. This process is explained by some new concepts that emerge, e.g. the concept of the identity mix (Balmer, 2001), based on the permanent communication of a given entity with the environment.

The instruments used for creating the image of a town or city should be connected with its most important attributes. If the authorities are unable to focus on the most important attributes and they highlight too many issues, the city's image will be unclear and indiscernible to the recipient. Being an attractive destination and having a unique cultural heritage are very popular distinguishing characteristics, which are commonly used by city and town authorities in their promotional activities (Przygodzki, Sokołowicz, 2008, p. 218). 
The image of a place can be influenced by such elements as the image of the whole country; the image of the brand's recipients; the images of competing entities; the status and experiences of the brand's recipients; the image of local authorities; as well as the history and traditions of the town or city (Szulce, Janiszewska, 2012, p. 52). These factors cannot be directly influenced by territorial units. Elements that can be influenced by the people responsible for shaping the image of a given destination include the brand symbol, i.e. the visual identity system; and brand identity, defined and communicated to target groups through selected marketing instruments. Other factors within people's control that determine the image include broadly understood infrastructure, economic climate, qualifications of the residents, local man-made attractions (Szulce, Janiszewska, 2012, p. 132), as well as other anthropogenic elements.

A comprehensive concept of building the image of a place that will enable managing the image in an optimal way should take into account the elements of visual identity mentioned above. The system of graphic standards for a territorial unit includes such components as the city brand logo; the coat of arms and flag (having a certain size, proportions and colours); city symbols (characteristic figures, monuments, buildings); city colours (combining them with other elements and symbols); typography (typeface of the city name and advertising materials); marking on the vehicles of city institutions; letterhead; and many others (Szromnik, 2012, p. 149 et seq.). A very important issue is the internal coherence of all the elements of the visual identity system as well as ensuring that it is aesthetic, harmonious and timeless in terms of its universality.

As already mentioned, the identity of a town or city is treated as a comprehensive collection of objective information about it. The information may relate to such areas as administration; transport; telecommunications; health care; investment, settlement, trade and tourist attractiveness; fairs and exhibitions; etc. Grouping this information has led to a formulation for the concept of town identity, which is based on three segments:

- corporate design for a town/city, which means town design understood as a coherent image of the place. It includes all the components that influence the appearance of the town or city. In addition to urban planning and architecture, the concept also includes other elements such as symbols, slogans, names, monuments and elements of infrastructure;

- corporate communications for a town/city, which means town communications understood as a transparent system for communicating with target groups. The basic forms of communicating marketing information by municipal authorities and institutions include festivals, exhibitions, anniversaries, celebrations, fairs, celebrations, etc. that involve the participation of recipient groups. Public relations, publicity and sponsorship activities play a key role in communications between town or city authorities and their internal and external stakeholders; 
- corporate behaviour for a town/city, which means town behaviour understood as a system of behaviours, sometimes also referred to as "town culture", which is formed by patterns of social behaviour; the personal standards of residents; their views on other territorial and ethnic groups; attitudes to emerging social pathologies; observance of the accepted rules of public safety and public order; compliance with climate protection requirements, etc. It should be noted that there are some interdependencies between the three elements but it would be difficult to arrange them chronologically or according to their importance. Each element originates in a different sphere and each has a dynamic impact on the others (Szromnik, 2016, pp. 148-152; Duczkowska-Piasecka, 2013, pp. 174-175).

There is a strong relationship between the concepts of identity and image, and, importantly, there is a feedback loop between them (Piechna, Renigier-Biłozor, 2010). This is because a properly constructed identity promotes the construction of an appropriate final image, and the current image of a territorial unit determines the features that must be included in the created identity.

\section{Positioning the image of a town or city}

The process of positioning the image of a territorial unit is aimed at securing a significant place in the perception of the target recipients of promotional messages. Among the addressees of the promotion-mix in place marketing, a number of internal and external groups of stakeholders can be distinguished (Ciechomski, Romanowski, 2016, p. 82). Internal recipients include permanent as well as occasional residents (for example students), seasonal workers, local entrepreneurs and investors, members of local authorities, employees and personnel of local government at various levels, employees of local institutions and public utility companies, representatives of local lobby groups, etc. External stakeholders include, among others, domestic and foreign tourists, potential residents, travellers, domestic and foreign investors and entrepreneurs, highly qualified employees, governmental organizations and agencies, national and foreign institutions and other entities.

Positioning helps a place to favourably distinguish itself from competitors, facilitates information processing, as well as generating positive attitudes towards a given destination. The main task of positioning is to strengthen the positive image that distinguishes the town or city from other agglomerations. It must be remembered that municipalities, towns, cities, districts and regions compete with each other for investors, tourists, highly qualified employees, residents who pay taxes and identify themselves with the place where they live, as well as a whole range of tangible and intangible resources. 
The positioning of a town's or city's image is based on the following: first, it needs to be established which cities/towns are its direct competitors, and then specific criteria are adopted to determine the place's position in relation to those competitors. Next, it is necessary to answer the question "How are the compared cities/towns perceived by the recipients of image-building campaigns?" It should be noted that a separate specific image of the city/town can be created for each target segment. Diagnosis of the current image of a spatial unit can be performed with the help of various measurement methods, taking into account the complexity of the place's image and its unique features (Staszyńska, 2013). Image research can be conducted on the basis of the functional characteristics of the place, defining physical and material aspects as well as psychological features related to the non-material, symbolic and emotional sphere (Keller, Aperia, Georgson, 2012, p. 5). The instruments that are most commonly used for image measurement are a 5- or 7-point Likert scale and a semantic differential scale (Glińska, Florek, Kowalewska, 2009, p. 70).

The strategies of positioning the image of towns and cities strive to present their offers as something special and unique: they possess and can offer customers exceptional resources, assets and utility. This process is based on specific criteria and aims to improve the image of the settlement unit promoted in the media. Selecting the criteria for positioning settlement units is not an easy decision. Formulating the specific criteria requires a knowledge of the behaviour of selected groups of entities, as well as a knowledge of operational methods and techniques (Glińska, 2016, pp. 106-109). Original examples of actions taken as part of the marketing positioning of cities such as Białystok, Bydgoszcz, Gdańsk, Gdynia, Grudziądz, Kraków, Lublin, and Łódź are presented in (Stępowski, 2015, p. 122 et seq.) but are too extensive to discuss them in detail in the present paper. It is worth mentioning, however, that the authorities of cities such as Kraków and Gdańsk undertake a whole range of creative activities that can serve as inspiration for others.

\section{Conclusions}

For territorial units, a favourable image is an extremely valuable intangible value because it is connected with the ability to influence the expected behaviour of the recipients of promotional activities (Ciechomski 2014, p. 370). Creating an optimal image of a territorial unit is a long-term endeavour. This process should not only be properly planned and implemented, but also appropriately monitored and modified. The ability of town or city authorities to react in crisis situations also plays a major role in the image creation process.

One of the most frequent mistakes in the marketing of cities and regions, including creating and positioning their image, is insufficient coherence and uniformity in the promotional message (Pogorzelski, 2012, p. 235). Another major issue is significant cuts in the expenditure 
on promotional activities of municipalities, towns and cities as a result of debts, which sometimes exceed half their annual budgets (Ciechomski, Romanowski, 2013, p. 112). The destructive impact of financial barriers is also illustrated by the fact that the most effective image-building activities require regular and constant presence in the media in order to secure an appropriate place in the perception of image campaign addressees. Irregular actions resulting from the size of towns' or cities' promotional budgets being determined solely by their current revenues and expenditures usually yields unsatisfactory results.

\section{References}

1. Balmer, J. (2001). Corporate Identity, Corporate Branding and Corporate Marketing Seeing Through the Fog. European Journal of Marketing, Bradford, 35, 3-4.

2. Budzyński, W. (2012). Kształtowanie wizerunku równoległego. Warszawa: Szkoła Główna Handlowa - Oficyna Wydawnicza.

3. Ciechomski, W. (2014). Determinanty podnoszenia konkurencyjności regionu i kreowania jego wizerunku. Marketing i Rynek, 10.

4. Ciechomski, W. (2015). Marketing terytorialny jako nowoczesna koncepcja kreowania wizerunku miast i regionów. Marketing i Rynek, 10.

5. Ciechomski, W. (2017). Ewolucja i implementacja marketingu terytorialnego. Marketing i Rynek, 10.

6. Ciechomski, W., Romanowski, R. (2016). Segmentacja nabywców produktu terytorialnego jako element budowania przewagi konkurencyjnej. Marketing i Rynek, 10.

7. Ciechomski, W., Romanowski, R. (eds.) (2013). Marketing terytorialny oparty na wiedzy. Poznań: Wydawnictwo Uniwersytetu Ekonomicznego.

8. Duczkowska-Piasecka, M. (2013). Marketing terytorialny. Jak podejść do rozwoju z korzyścia dla wszystkich. Warszawa: Difin.

9. Florek, M. (2013). Podstawy marketingu terytorialnego. Poznań: Wydawnictwo Uniwersytetu Ekonomicznego.

10. Florek, M., Augustyn, A. (2011). Strategia promocji jednostek samorzadu terytorialnego zasady i procedury. Warszawa: Fundacja Best Place - Europejski Instytut Marketingu Miejsc.

11. Glińska, E. (2008). Zarządzanie procesem kształtowania wizerunku miasta wśród jego mieszkańców na przykładzie Zambrowa. Toruń: Wydawnictwo Adam Marszałek.

12. Glińska, E. (2016). Budowanie marki miasta. Koncepcje, warunki, modele. Warszawa: Wydawnictwo Wolters Kluwer SA.

13. Glińska, E., Florek, M., Kowalewska, A. (2009). Wizerunek od koncepcji do wdrożenia. Warszawa: Wydawnictwo ABC. 
14. Hankinson, G. (2004). Relational network brands: Towards a conceptual model of place brands. Journal of Vacation Marketing, 10, 2.

15. Hosany, S., Ekinci, Y., Ujsal, M. (2006). Destination Image and Destination Personality: an Application of Branding Theories to Tourism Places. Journal of Business Research, 59.

16. Kall, J., Kłeczek, R., Sagan, A. (2006). Zarzązanie marka. Kraków: Oficyna Ekonomiczna.

17. Keller, K.L., Aperia, T., Georgson, M. (2012). Strategic Brand Management. A European Perspective. Harlow: Pearson Education.

18. Markowski, T. (ed.) (2006). Marketing terytorialny. Warszawa: Komitet Przestrzennego Zagospodarowania Kraju PAN.

19. Neal, W., Strauss, R. (2008). Value Creation: the Power of Brand Equity. Ohio: Cengage Learning.

20. Orfin-Tomaszewska, K. (2016). Polityka promocji w kreowaniu wizerunku produktu turystycznego. Szczecin: Wydawnictwo Naukowe Uniwersytetu Szczecińskiego.

21. Piechna, A., Renigier-Biłozor, M. (2010). Wyzwania marketingu terytorialnego a kreowanie tożsamości miast w Polsce. Acta Scientiarum Polonorum, 9.

22. Pogorzelski, J. (2012). Praktyczny marketing miast i regionów. Warszawa: Oficyna a Wolters Kluwer business.

23. Przygodzki, Z., Sokołowicz, E. (2008). Nowoczesne miasto: badania, instrumenty, analizy. Łódź: Wydawnictwo Biblioteka.

24. Raszkowski, A. (2013). Marketing miejsc w kontekście wzmacniania i kształtowania tożsamości terytorialnej. In: A. Smalec (ed.), Marketing przyszłości. Trendy, strategie, instrumenty. Orientacja marketingowa jednostek samorzadu terytorialnego i instytucji publicznych. Zeszyty Naukowe, 775. Problemy Zarzadzania, Finansów i Marketingu, 30. Szczecin: Wydawnictwo Naukowe Uniwersytetu Szczecińskiego.

25. Staszyńska, K.M. (2013). Marka, konsument, badacz: spotkania na rynku. Warszawa: Oficyna Wolters Kluwer business.

26. Stępowski, R. (2015). Marketing terytorialny. Jak zbudować i wypromować markę miejscowości. Rawa Mazowiecka: Wydawnictwo Roster.

27. Szromnik, A. (2012). Marketing terytorialny. Miasto i region na rynku. Warszawa: Wolters Kluwer Polska.

28. Szromnik, A. (2016). Marketing terytorialny miasto i region na rynku. Warszawa: Wolters Kluwer Polska SA.

29. Szulce, H., Janiszewska, K. (2012). Zarzadzanie marką. Poznań: Wydawnictwo Uniwersytetu Ekonomicznego. 